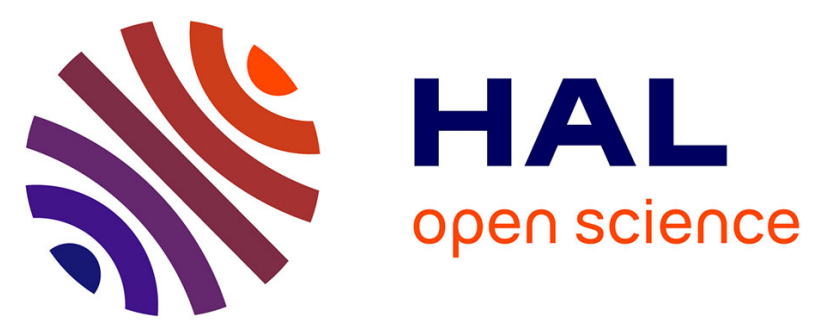

\title{
Collection and management of selected comorbidities and their risk factors in chronic inflammatory rheumatic diseases in daily practice in France
}

Laure Gossec, Athan Baillet, Sabrina Dadoun, Claire Daien, Francis Berenbaum, Emmanuelle Dernis, Françoise Fayet, Christophe Hudry, Maryse Mezieres, Sophie Pouplin, et al.

\section{To cite this version:}

Laure Gossec, Athan Baillet, Sabrina Dadoun, Claire Daien, Francis Berenbaum, et al.. Collection and management of selected comorbidities and their risk factors in chronic inflammatory rheumatic diseases in daily practice in France. Joint Bone Spine, 2016, 10.1016/j.jbspin.2016.05.012 . hal-01340133

\section{HAL Id: hal-01340133 \\ https://hal.sorbonne-universite.fr/hal-01340133}

Submitted on 30 Jun 2016

HAL is a multi-disciplinary open access archive for the deposit and dissemination of scientific research documents, whether they are published or not. The documents may come from teaching and research institutions in France or abroad, or from public or private research centers.
L'archive ouverte pluridisciplinaire HAL, est destinée au dépôt et à la diffusion de documents scientifiques de niveau recherche, publiés ou non, émanant des établissements d'enseignement et de recherche français ou étrangers, des laboratoires publics ou privés. 
Collection and management of selected comorbidities and their risk factors in chronic inflammatory rheumatic diseases in daily practice in France

Laure GOSSEC ${ }^{1}$, Athan BAILLET ${ }^{2^{*}}$, Sabrina DADOUN ${ }^{3^{*}}$, Claire DAIEN ${ }^{4^{*}}$, Francis BERENBAUM ${ }^{5}$, Emmanuelle DERNIS ${ }^{6}$, Françoise FAYET $^{7}$, Christophe HUDRY ${ }^{8}$, Maryse MEZIERES ${ }^{8}$, Sophie POUPLIN ${ }^{9}$, Christophe RICHEZ $^{10}$, Alain SARAUX ${ }^{11}$, Carine SAVEL ${ }^{7}$, Eric SENBEL ${ }^{12}$, Martin SOUBRIER ${ }^{7}$, Laëtitia SPARSA ${ }^{13}$, Daniel WENDLING ${ }^{14}$ and Maxime DOUGADOS ${ }^{15}$

*Athan Baillet, Sabrina Dadoun and Claire Daien are co-second authors

1. Sorbonne Universités, UPMC Univ Paris 06, Institut Pierre Louis d'Epidémiologie et de Santé Publique, GRC-UPMC 08 (EEMOIS); AP-HP, Pitié Salpêtrière Hospital, Department of Rheumatology, Paris, France. laure.gossec@psl.aphp.fr

2. Université Joseph Fourier, GREPI - CNRS, Grenoble Hospital, Department of Rheumatology, France.

3. AP-HP, Pitié Salpêtrière Hospital, Department of Rheumatology, Paris, France.

4. Department of Rheumatology, CHU Montpellier and UMR5535 CNRS, Montpellier, France.

5. Sorbonne University, UPMC Université Paris 06, UMRS 938, DHU i2B, Department of Rheumatology, AP-HP, Saint-Antoine Hospital, Paris, France.

6. Department of Rheumatology, Le Mans Hospital, Le Mans, France.

7. Department of Rheumatology, Gabriel Montpied University Hospital, ClermontFerrand, France.

8. AP-HP, Cochin Hospital, Department of Rheumatology, Paris, France.

9. Department of Rheumatology, Bois-Guillaume Hospital, Rouen, France.

10. Department of Rheumatology, Pellegrin Hospital, Bordeaux University, Bordeaux, France.

11. Department of Rheumatology, CHU de la Cavale Blanche, Boulevard Tanguy Prigent, Brest, France ; EA 2216, INSERM ESPRI, ERI29 Université Bretagne Occidentale, Brest, France.

12. AP-HM, RheumatologyDepartment, Sainte Marguerite Hospital, Marseille, France.

13. Hospital Center of Mulhouse, Mulhouse, France.

14. Department of Rheumatology, CHRU Besançon, and EA 4266, Université de Franche-Comté, Besançon, France.

15. Paris Descartes University. Department of Rheumatology - Hôpital Cochin. Assistance Publique - Hôpitaux de Paris. INSERM (U1153): Clinicalepidemiology and biostatistics, PRES Sorbonne Paris-Cité. Paris,

France.maxime.dougados@aphp.fr

Corresponding author:

Prof. Laure Gossec, Service de Rhumatologie, Hôpital Pitié Salpétrière et Université Paris 06, 47-83 Bd Hôpital 75013 Paris France laure.gossec@aphp.fr

Manuscript: 3691 Words, 2 tables, 60 refs, 2 online tables 
Disclosures of of interest: Maxime DOUGADOS has received honorarium fees from Abbvie for his participation as the convenor of this initiative. Athan BAILLET, Claire DAIEN and Sabrina DADOUN have received honorarium fees from Abbvie for their participation as fellows of this initiative. All the other coauthors have received honoraria from Abbvie as members of the scientific committee.

Acknowledgments:

Funding: this study has been conducted thanks to an unrestricted grant from Abbvie France. Work derived from the Rencontres d'Experts en Rhumatologie program, which was sponsored by AbbVie France. AbbVie employees were present during the Rencontres d'Experts en Rhumatologie meetings, but did not influence the scientific discussions. AbbVie did not review the content or have influence on this manuscript.

The authors thank Pr Olivier Epaulard for his critical review of the infection paragraphs and Margaux Orange for logistic assistance and the 110 experts for input during the meeting.

Key words: comorbidities, rheumatoid arthritis, spondyloarthritis, management 


\section{ABSTRACT (245 words)}

Background: In chronic inflammatory rheumatic diseases (CIRDs), comorbidities such as cardiovascular disease and infections are sub-optimally managed. EULAR recently developed points to consider to collect and report comorbidities. The objective of this present study was to develop a pragmatic guide to collect, report and propose management recommendations for comorbidities, from a rheumatologist perspective.

Methods: The collection and reporting of comorbidities and risk factors was adapted from the EULAR points to consider. To develop management recommendations, the process comprised (1) systematic literature reviews by 3 fellows and (2) a 2-day consensus process involving 110 experts (rheumatologists and health professionals). Votes of agreement (Likert 1-5 where 5 indicates full agreement) were obtained.

Results: The six selected comorbidities were ischemic cardiovascular diseases, malignancies, infections, diverticulitis, osteoporosis and depression. The literature review retrieved 97 articles or websites, mostly developed for the general population. The consensus process led to reporting presence of comorbidities, current treatment, risk factors (e.g. hypertension), screening (e.g. mammography) and prevention (e.g. vaccination). Management recommendations include physical examination (e.g. blood pressure or lymph node examination), prescribing screening procedures, and interpreting results to refer in a timely manner to appropriate other health professionals. Agreement was high (mean \pm standard deviation, 4.37 \pm 0.33 ).

Conclusions: Using an evidence-based approach followed by expert consensus, this initiative furthers the dissemination in France of the EULAR points to consider, and clearly defines what part of the management of comorbidities is potentially within the remit of rheumatologists. This initiative should facilitate systematic management of patients with CIRDs. 


\section{INTRODUCTION}

Chronic inflammatory rheumatic diseases (CIRDs) comprise different diseases such as rheumatoid arthritis (RA), spondyloarthritis $(\mathrm{SpA})$, and connective tissue disorders. It is known that either CIRDs or their treatments are associated with an increased prevalence or a decreased management of certain comorbidities: thus, cardiovascular diseases and cardiovascular risk factors (such as hypertension or hyperlipidemia),[1-3] infections,[4, 5] depression[6] and osteoporosis [7] are more frequent in patients with CIRDs, whereas there is no demonstrated increase but sub-optimal management compared to the general population of other comorbidities such as malignancies or gastrointestinal diseases.[5, 8] For example, the screening for the detection of breast cancer (a cancer which is not more frequent in CIRDs than in the general population) by mammography may be less frequently performed in women with CIRDs.[9]

Recently, The European League Against Rheumatism (EULAR) developed points to consider for the reporting and collection of comorbidities in CIRDs.[10] In these points, EULAR stipulated that rheumatologists should collect information regarding comorbidities in a standardized way. A pragmatic collection form was developed to collect information relevant to 6 selected comorbidities: ischemic cardiovascular diseases, malignancies, infections, gastrointestinal diseases, osteoporosis and depression.[10] However, EULAR did not give indications on how to manage the comorbidities or risk factors. This was not done for 2 reasons: (a) it is unclear who should be responsible for managing such comorbidities; $[[9,11]$ and (b) management of comorbidities may be country-specific (e.g. levels of cholesterol necessitating intake of lipid-lowering drugs may vary across countries).[10, 12, 13]

In the present initiative, we aimed to implement the EULAR points to consider for the collection and reporting of comorbidities in a national context (France) and to develop management recommendations for selected comorbidities and risk factors, based on CIRDspecific and general population recommendations, but from a rheumatologist perspective, i.e., taking into account what will be within the rheumatologist's remit and when to refer the patient to other physicians. The final aim was to develop a pragmatic document including both the collection and the management of each comorbidity, for use in clinical practice.

\section{METHODS}

This process included literature reviews and a consensus process in France, in accordance with previous Rencontres d'Experts en Rhumatologie (RER) and 3E (Evidence, Expertise, Exchange) initiatives.[14, 15] 


\section{Decisions on target population and target comorbidities}

A face-to-face meeting of the steering group took place in March 2015. The group included a convenor (MD), a facilitator (LG), 3 ( $A B, S D, C D), 10$ rheumatologist experts and 3 rheumatology nurses. Three of these were previously involved in the recent EULAR points to consider regarding comorbidities.[10] Based on the EULAR points and on discussions, the target population in terms of patients who should benefit from this initiative, and the list of comorbidities to be considered was developed.

\section{Systematic literature reviews}

Systematic literature reviews were performed for each comorbidity. These reviews used the EULAR review as a basis [10] and comprised (a) a complementary review for connective tissue diseases (not formally included in the EULAR review) and (b) a review regarding management of comorbidities in particular by checking the existence of specific recommendations for management including from the French Health authorities (HAS: Haute Autorité de Santé).[16] The objective was to collect published and unpublished recommendations and guidelines for each of the selected comorbidities. This systematic literature review was performed by 3 fellows (AB, SD, CD) from April to September 2015. Detailed information on the process is given in online supplementary Table 1.

\section{Consensus process}

During a second face-to-face meeting, the steering group developed a draft document dealing with the six groups of comorbidities, and including, for each one, questions to ask for 1) the reporting (i.e. occurrence) of the comorbidity; 2) whether screening (e.g. mammography) or assessment of risk factors (e.g. hypertension and factors for diabetes) had been undertaken; 3) the uptake of any preventive measures (e.g. vaccination), and 4) management recommendations. These include prescribing screening procedures, treatment introductions, and/or referrals to appropriate other health professionals.

Then a two-day physical meeting took place in October 2015. Here, 104 physicians and 6 other health professionals (nurses) participated. The comorbidities were split into 3 workshops, each repeated 3 times, every attendee participating at each workshop once. The literature review and the draft document were presented, and the document was adapted according to decisions taken by the group. After the 9 workshops, the 3 versions of each workshop's document were compared by the steering group and a final consensus version was obtained when possible, or 2 alternative versions if consensus could not be reached.

The next day, the consensus versions were presented to the whole group and final decisions were taken by majority voting. 
Votes for levels of agreement (Likert 1-5 where 5 indicates full agreement) were obtained from the group for each part of the document.

\section{RESULTS}

\section{Target population and choice of selected comorbidities}

The group considered that this work would be applicable to all patients with CIRDs, including $\mathrm{RA}, \mathrm{SpA}$, psoriatic arthritis, connective tissue disorders and would be useful also for patients with vasculitis and potentially multi-site osteoarthritis.

This work focused on 6 selected comorbidities: (1) cardiovascular diseases i.e. myocardial infarction, angina, ischemic stroke, transient ischemic attack, heart failure, and peripheral arterial disease, as well as diseases that are also risk factors for ischemic heart disease such as hypertension, diabetes, or dyslipidaemia; (2) malignancies: haematologic, skin, lung, colon, breast, prostate, and uterus; (3) infections: serious, repeated non-serious, tuberculosis, non-tuberculosis opportunistic, as well as vaccinations. Oral hygiene was added; (4) gastrointestinal diseases: gastro-duodenal ulcers and diverticulitis; (5) osteoporosis and (6) depression.

\section{Systematic literature reviews}

A total of 5317 abstracts were retrieved by the searches, of which in the end 64 were included in the final qualitative synthesis, as well as 33 websites/unpublished data (Table 1). Of these, 42 were already included in the EULAR systematic literature review [10] (Table 1). Most of the available recommendations were recommendations for the general population. From each selected manuscript, the following information was extracted: definition of the comorbidity, how to report its occurrence, proposed screening strategy and proposed screening time interval, and proposed management strategies. All collected data were compiled in tables to help appraisal.

\section{Consensus for each comorbidity}

Table 2 summarises the points relevant to each comorbidity, also presented in French in extenso as online supplementary Table 2 . There was high agreement within the Task 
Force regarding these points (Table 2): the mean agreement overall was $4.37 \pm 0.33$ (1-5 scale).

\section{Ischemic cardiovascular disease}

Here, the proposed management is in agreement with the recent EULAR recommendations.[17] For total cardiovascular risk estimation, EULAR recommends this assessment for all patients with RA, ankylosing spondylitis or psoriatic arthritis at least once every 5 years and following major changes in anti-rheumatic therapy; [17] the frequency of assessment for each aspect of cardiovascular disease was the object of much discussion.

\section{Hypertension}

Regarding blood pressure, this was felt to be part of usual clinical examination and although no recommendations were found for a proposed frequency, the group recommended blood pressure measurement by the rheumatologist at least once a year (and more frequently if known hypertension, non steroidal drug treatment or in patients with lupus, ie, at every visit). $[18,19]$ A control then referral is recommended if blood pressure $\geq 140 / 90 \mathrm{mmHg}$.

\section{Diabetes}

In the general population, the French health authority states glycaemia should be assessed i) every 1-3 years in patients "at risk" according to the FINDRISK score or patients with "at risk" therapy such as glucocorticoids and ii) every year in pre-diabetic patients (ie, if fasting glycaemia is between 1.1 and $1.25 \mathrm{~g} / \mathrm{ll}$.[20] Here, the consensus was to check for undiagnosed diabetes every 1 to 3 years, thus considering CIRD patients as 'at risk'. The frequency will depend on the presence of risk factors according to FINDRISK including high body mass index, high waist circumference, past hyperglycaemia, family history of diabetes, and glucocorticoid intake.[20] If fasting blood sugar is twice $\geq 7.0 \mathrm{mmol} / \mathrm{l}(1,26 \mathrm{~g} / \mathrm{l})$ or if nonfasting blood sugar is $\geq 11.1 \mathrm{mmol} / \mathrm{l}(2 \mathrm{~g} / \mathrm{l})$, the recommendation was to refer the patient.

Regarding known diabetes, the group recommended measurement of $\mathrm{HbA} 1 \mathrm{c}$ and referral if the target is not attained - the target is usually $7 \%$ but depends on age and other health issues).[21-23] Furthermore, weight loss is recommended if high body mass index is detected.

Total cardiovascular risk estimation

Here, in accordance with current European recommendations, it was decided to assess the Heart-SCORE and to apply a corrective factor of 1.5 in RA (as proposed by European experts), and to perform this assessment at least every 5 years.[17]

Patients with high risk (Heart-SCORE $\geq 5 \%$ ) are usually referred to cardiologists.[24] The European recommendations of cardiology state that patients with ultrasonography carotid plaques should be classified at very high risk whatever the Heart-SCORE.[24, 25] Screening 
for asymptomatic atherosclerotic plaques by use of carotid ultrasound has been reported to evidence carotid plaques in up to $65 \%$ of RA patients at moderate total cardiovascular risk (Heart-SCORE risk 1-5\%) thus most patients with moderate risk will be reclassified after carotid ultrasound as very high risk patients.[26] The consensus of this group was that the decision to perform carotid ultrasound, but also the interpretation of this examination and subsequent treatment decisions should be made by a specialist; thus the group proposed to refer all patients with a risk $>1 \%$ (Table 2) though we are aware this will result in frequent referrals.

\section{Dyslipidaemia}

The assessment of dyslipidaemia is recommended in accordance with published EULAR guidelines at least every 5 years and following major changes in anti-rheumatic therapy, ideally when disease activity is stable or in remission.[17]. The target values of LDL cholesterol depend on total cardiovascular risk estimation.[25] Although some rheumatologists prescribe statins, the group consensus was to refer the patient if needed.

\section{Heart failure}

The occurrence of this comorbidity is reported, and symptoms evocative of heart failure lead to referral.[27]

\section{Malignancies}

Screening for malignancies is useful in the general population.[28-30] The rheumatologist's role includes clinical examination and recommendation or prescription of tests e.g. mammography. In case of any abnormalities, the rheumatologist will refer the patient (Table 2).

\section{All cancers}

The group considered that the report of the occurrence of a cancer should be as simple as possible even if other information might be of interest for the treatment decision of a particular patient. Consequently, reporting the date of diagnosis was recommended but treatment received, remission or not, and length of remission were not.

\section{Breast cancer}

A mammography is recommended every 2 years for ages 50-74.[31] In case of family history or personal history of breast cancer, personalized care is needed.

\section{Cervix cancer}

A smear is recommended every 3 years for women between 25 and 65 years old, with sexual activity, after 2 normal smears in the first two years. Controls may be more frequent in lupus patients.[32] If a smear is abnormal (dysplasia, infection, cancer), personalized care is required.[33] 
Discrepancies exist between urologists' and oncologists' recommendations.[34-36] The group recommended no systematic screening but a specific visit (to the general practitioner or an urologist) in case of (i) urologic symptoms or (ii) in men older than 45 with either a familial history of prostate cancer (2 or more prostate cancers at any age or 1 or more prostate cancer before 55 years old), or of Afro-Caribbean origin.

\section{Lung cancer}

The group was aware of a specific screening in patients with a smoking history in the United States and in some European countries.[37] However, no systematic screening was recommended due to no existing recommendations in France at this time and due to the absence of specific centres which could do the screening and the follow-up of these patients. The group recommended to report the smoking status and the number of pack-years, and to address smokers to the general practitioner to try to quit smoking.

Lymphoma

The group recommended lymph nodes palpation every year.

\section{Colorectal cancer}

In the absence of risk factors, it is recommended to screen for colorectal cancer in patients of ages 50-74, every other year (or 5 years after a normal colonoscopy), by a faecal test (either immunochemical test or occult blood test).[38] If a risk factor is present (e.g., personal history of inflammatory bowel disease or of polyps), patients should get a personalized care.

\section{Skin cancer}

The group recommended to visit a dermatologist at least once to assess for skin cancer, then the dermatologist will decide the frequency of these visits.

\section{Infections}

\section{History of infections}

Tuberculosis, including active tuberculosis and positive tests for tuberculosis should be collected. In case of risk factors, it is proposed to screen for tuberculosis (Table 2). [39,40] Other infections are collected: this includes serious infections (defined as an infection which results in life-threatening, in requiring hospitalization or prolongation of existing hospitalization, or may resulting in persistent or significant disability/incapacity), repeated infections with their localisation, history of viral infections such as human immunodeficiency virus (HIV), hepatitis B or C, zoster, and herpes simplex virus; and opportunistic infections (for which a list is given to help the clinician) (online supplementary Table 2).[4,10,40] Although considering that such collection was critical as it could influence treatment decisions, the group did not propose any specific screening or treatment guidelines, except for tuberculosis; ; but lowest possible doses of glucocorticoids should be used at all times given the links with infections. 


\section{Predisposing factors for infections}

A visit to the dentist is recommended every year, in view of both the infectious risk represented by poor dental hygiene, and potential links between some CIRDs and periondontitis.[41,42]

The group decided to report the presence of "chronic bronchitis" rather than chronic obstructive pulmonary disease (COPD) because chronic bronchitis is clinically defined (as a cough that occurs every day with sputum production that lasts for at least 3 months, two years in a row), whereas COPD is defined by spirometry parameters. The proposal is to screen for COPD and to refer patients based on a questionnaire (ref) to either a general practitioner or a pneumologist.[43, 44]

Lung fibrosis is mainly an extra-articular manifestation of inflammatory rheumatism such as RA or a side effect of DMARDs [45]. As it is not a comorbidity per se, lung fibrosis was considered beyond the scope of this paper.

\section{Vaccinations}

Diphtheria/tetanus/poliomyelitis, influenza and pneumococcus vaccinations are strongly recommended, whereas our suggestions for hepatitis $B$ vaccination and herpes zoster vaccination (Zostavax®) are more informative than prescriptive. [5, 46-49]

Although the risk of herpes zoster is increased in patients treated with TNF inhibitors and Jak inhibitors, we did not give any strong recommendation because i) of a lack of efficacy and safety data in patients with CIRDs, ii) the fact that herpes zoster vaccination is recommended only in the general population after 65 in France and iii) it is a live vaccine and is contraindicated in patients treated with immunosuppressants (Table 2). [47-51]

Given the lack of consensus regarding pertussis and measles vaccinations, no recommendations were formulated.[4] Shingles vaccination with Varivax®, a live attenuated vaccine, was discussed but given the limited data available for prevalence of shingles and efficacy of shingles vaccination, the group did not recommend it. [52]

The group decided to record patients declining vaccination as it is a frequent issue in patients with CIRDs.[1]

\section{Gastrointestinal diseases}

On top of colon/rectum cancer and inflammatory bowel diseases (collected as a risk factor for colon cancer) addressed in the "malignancies" section, the group selected diverticulitis as a comorbidity of interest, mainly because of its increased incidence ( $0.4 \%$ in RA patients) and severity in immunosuppressed patients. [5] When reporting the history of diverticulitis, experts raised the question of possible confusion between diverticulosis and diverticulitis and suggested to check whether patients were hospitalized, received antibiotics or underwent CT 
scan. Contrary to the EULAR Task Force [10], we decided not to assess peptic ulcer risk factors because the group felt that peptic ulcer is usually screened for when prescribing symptomatic treatments such as steroids or non steroidal anti inflammatory drugs.

\section{Osteoporosis}

The history of severe and non-severe osteoporotic fractures is collected. Given that a significant number of osteoporotic vertebral fractures are asymptomatic, the group recommended checking for vertebral fractures using imaging for patients with a height loss of $4 \mathrm{~cm}$ or more compared to their height at the age of 20.[5] It was decided not to report a history of osteoporosis (eg through the question : do you have osteoporosis?) as this may lead to over-reporting.[53]

The group proposed to assess bone mineral density by DEXA as recommended for patients at risk of osteoporosis, and also at least once in patients with CIRDs.[54]

The risk of osteoporosis should be assessed by calculation of a score for risk of osteoporotic fracture at 10 years (i.e., FRAX).[55] The group recommended to calculate the FRAX for patients aged 40 or above with bone density T Score >-3 standard deviations, in case of (i) non-severe fracture or (ii) of presence of risk factor(s) .[55] The FRAX interpretation depends on the country and on age; this group recommended to consider anti-osteoporotic treatment if FRAX values were beyond the published intervention levels (Table 2).

Although some rheumatologists collect more risk factors than those proposed here, it was considered that for a systematic screening of osteoporosis in patients coming for another motive (eg, a 26 year old male with axial spondyloarthritis) such data collection was sufficient. $[9,54,55]$

Regarding management recommendations, this comorbidity is apart since the specialists for osteoporosis are rheumatologists thus naturally, no referral is recommended. It was decided to not give detailed treatment recommendations within the scope of this project, but rather to refer rheumatologists to current osteoporosis management recommendations.[56]

\section{Depression}

It is proposed to collect the existence of depression, and as risk factors, a history of depression or anti-depressant drug intake. Recognising the frequency of depression in these patients and its impact, the group proposed to collect the existence of depression / antidepressant drug intake but not perform any extensive screening for depression since such screening has been reported to have conflicting efficacy.[6, 57-59] 


\section{DISCUSSION}

Using an evidence-based approach followed by expert consensus, the current work furthers the dissemination and the adaptation to a national context of the EULAR comorbidities initiative and clearly defines what part of the management of comorbidities is potentially within the remit of rheumatologists. The pragmatic document developed should be of use both for annual reviews in hospitals by the rheumatology team, and for private practice rheumatologists in daily practice.

Some comorbidities such as fibromyalgia (or fatigue though this is a symptom) would be important to collect but are missing in this project. However the group anticipated that the screening of a broader scope of comorbidities would make the final process too complex or too extensive to be implemented. Furthermore, this initiative is in accordance with the EULAR initiative.[10] Compared to the EULAR comorbidity project, this group added diverticulitis, prostate cancer and herpes zoster vaccination but excluded peptic ulcer since it appeared to the group that the systematic screening of risk factors for peptic ulcer was not useful but rather should be performed in specific cases (eg non steroidal anti inflammatory drug prescription).

The systematic literature review confirmed that specific CIRDs-dedicated recommendations for comorbidities are scarce.[2,4,40,54] In most cases, recommendations for the management of comorbidities in CIRDs were extrapolated from those in the general population; Reaching an agreement on what exactly falls within the remit of the rheumatologist was sometimes challenging. Although there is always some personal opinion in consensus processes, we feel the rigorous methodology of the systematic literature reviews and the high number of rheumatologists participating in this consensus exercise are strengths of this project. Furthermore, all these rheumatologists are practicing physicians with clinics, which strengthens the feasibility aspects of such a systematic screening and management programme. Although the work was based on national recommendations, the results are in accordance with other recent EULAR recommendations.[2,4, 10,40,46,54] Finally, we consider this project as highly useful to rheumatologists since we propose not only screening and collection questions but also practical management recommendations for each comorbidity, including when and who to refer to other specialists. Thus, this is the first time the exact limits of the rheumatologist role when dealing with comorbidities, has been clearly defined. It is important to note that dealing better with comorbidities should not be seen as replacing high-quality assessment and management of rheumatological conditions which remain at the heart and core of rheumatology work. 
Regarding the management recommendations, some are specific to France as proposed by the national High Authority of Health but many will be applicable across countries. It would be interesting to compare our results with similar initiatives from other countries.

Systematic screenings have been found to be useful for patients, as they draw attention to comorbidities that might otherwise be overlooked.[9,11] The time necessary for this screening raises the question of where it should be optimally performed. Should it be the rheumatologist, perhaps as a dedicated outpatient visit, or a rheumatology nurse e.g. during a systematic yearly review? This project does not answer this question but hopefully encourages a coherent and uniform approach for a review of comorbidities for people with CIRDs and defines the role of the rheumatology team in this regard.

It was difficult to propose precise screening intervals for many of the comorbidities. For total cardiovascular risk estimation, we chose 5 years as proposed by the EULAR task force [17] but for many other comorbidities it was not possible to propose a data-driven optimal interval. However, we believe our proposals will be useful for periodical reviews which might at the minimum be proposed every 5 years (for all comorbidities).

A next step involving patient is now under way, to develop a lay version of the reporting form, i.e., to evaluate in which way patients can self-complete part of the information to facilitate the process. [60]

Dissemination and implementation of recommendations is often an issue. In the present case, it is hoped that the proposed pragmatic form will facilitate this. In any case, further assessment of the feasibility of the document fulfilment and its dissemination will be warranted. In particular, implementation in private practices should be further assessed. Finally, this initiative will necessitate regular updates as some recommendations may change over time such as vaccination patterns or cardiovascular risk assessment. 


\section{REFERENCES}

1. Maradit-Kremers H, Crowson CS, Nicola PJ, et al. Increased unrecognized coronary heart disease and sudden deaths in rheumatoid arthritis: a population-based cohort study. Arthritis Rheum 2005;52:402-11.

2. Peters MJ, Symmons DP, McCarey D, et al. EULAR evidence-based recommendations for cardiovascular risk management in patients with rheumatoid arthritis and other forms of inflammatory arthritis. Ann Rheum Dis 2010;69:325-31.

3. Nurmohamed MT, Heslinga M, Kitas GD. Cardiovascular comorbidity in rheumatic diseases. Nat Rev Rheumatol. 2015;11:693-704.

4. van Assen S, Agmon-Levin N, Elkayam O, et al. EULAR recommendations for vaccination in adult patients with autoimmune inflammatory rheumatic diseases. Ann Rheum Dis 2011;70:414-22.

5. Dougados M, Soubrier M, Antunez A, et al. Prevalence of comorbidities in rheumatoid arthritis and evaluation of their monitoring: results of an international, cross-sectional study (COMORA). Ann Rheum Dis 2014;73:62-8.

6. Matcham F, Rayner L, Steer S, et al. The prevalence of depression in rheumatoid arthritis: a systematic review and meta-analysis. Rheumatology 2013;52:2136-48.

7. Briot K, Roux C. Glucocorticoid-induced osteoporosis. RMD Open. 2015 Apr 8;1:e000014.

8. Moltó A, Etcheto A, van der Heijde D, et al. Prevalence of comorbidities and evaluation of their screening in spondyloarthritis: results of the international cross-sectional ASASCOMOSPA study. Ann Rheum Dis. 2015 Oct 21. pii: annrheumdis-2015-208174. doi: 10.1136/annrheumdis-2015-208174. [Epub ahead of print]

9. Dougados M, Soubrier M, Perrodeau E, et al. Impact of a nurse-led programme on comorbidity management and impact of a patient self-assessment of disease activity on the management of rheumatoid arthritis: results of a prospective, multicentre, randomised, controlled trial (COMEDRA). Ann Rheum Dis. 2015;74:1725-33.

10. Baillet A, Gossec L, Carmona L, et al. Points to consider for reporting, screening and preventing selected comorbidities in chronic inflammatory rheumatic diseases in daily practice: A EULAR initiative. Ann Rheum Dis. 2016 Mar 16. pii: annrheumdis-2016-209233. doi: 10.1136/annrheumdis-2016-209233. [Epub ahead of print]

11. Gossec L, Salejan F, Nataf H, et al. Challenges of cardiovascular risk assessment in the routine rheumatology outpatient setting: an observational study of 110 rheumatoid arthritis patients. Arthritis Care Res 2013;65:712-7.

12. Loza E, Lajas C, Andreu JL, et al. Consensus statement on a framework for the management of comorbidity and extra-articular manifestations in rheumatoid arthritis. Rheumatology international 2015;35:445-58. 
13. Curtis JR, Arora T, Narongroeknawin P, et al. The delivery of evidence-based preventive care for older Americans with arthritis. Arthritis Res Ther 2010;12:R144.

14. Mouterde G, Baillet A, Gaujoux-Viala C, et al. Optimizing methotrexate therapy in rheumatoid arthritis: a systematic literature review. Joint Bone Spine. 2011;78:587-92.

15. Machado P, Castrejon I, Katchamart W, et al. Multinational evidence-based recommendations on how to investigate and follow-up undifferentiated peripheral inflammatory arthritis: integrating systematic literature research and expert opinion of a broad international panel of rheumatologists in the 3E Initiative. Ann Rheum Dis. 2011;70:15-24.

$16 \mathrm{http}: / / w w w . h a s-s a n t e . f r / p o r t a i l / j \mathrm{cms} / \mathrm{c}$ 1101438/fr/tableau-des-recommandations-debonne-pratique accessed January 27, 2016.

17 Nurmohamed M. EULAR recommendation update on cardiovascular disease in RA. Ann Rheum Dis 2015;74(Suppl2): 9.

18. Blacher J, Halimi JM, Hanon $O$, et al; Société française d'hypertension artérielle. [Management of arterial hypertension in adults: 2013 guidelines of the French Society of Arterial Hypertension]. Presse Med. 2013;42:819-25.

19. Arnaud L, Mathian A, Adoue D et al. [Screening and management of cardiovascular risk factors in systemic lupus erythematosus: Recommendations for clinical practice based on the literature and expert opinion]. Rev Med Interne. 2015;36:372-80.

20 Actualisation du référentiel de pratiques de l'examen périodique de santé; Prévention et dépistage du diabète de type 2 et des maladies liées au diabète 2014. http://www.hassante.fr/portail/jcms/c 2012494/fr/prevention-et-depistage-du-diabete-de-type-2-et-des-

maladies-liees-au-diabete accessed January 27, 2016.

21 International Diabetes Federation Guideline Development Group. Global Guideline for Type 2 Diabetes. Diabetes research and clinical practice 2014; 104:1-52.

22 Guide parcours de soins Diabète de type 2 de l'adulte - Guide maladie chronique - Avr. 2014. http://www.has-sante.fr/portail//cms/c 1735060/fr/guide-parcours-de-soins-diabete-detype-2-de-l-adulte accessed January 27, 2016.

23 Rydén L, Grant PJ, Anker SD, et al. ESC Guidelines on diabetes, pre-diabetes, and cardiovascular diseases developed in collaboration with the EASD. Eur Heart J. 2013 Oct;34):3035-87.

24 Perk J, De Backer G, Gohlke H, et al. European Guidelines on cardiovascular disease prevention in clinical practice (version 2012). The Fifth Joint Task Force of the European Society of Cardiology and Other Societies on Cardiovascular Disease Prevention in Clinical Practice (constituted by representatives of nine societies and by invited experts). Eur Heart J. 2012;33):1635-701. 
25 European Association for Cardiovascular Prevention \& Rehabilitation, Reiner Z, Catapano $A L$, De Backer G, et al. ESC/EAS Guidelines for the management of dyslipidaemias: the Task Force for the management of dyslipidaemias of the European Society of Cardiology (ESC) and the European Atherosclerosis Society (EAS). Eur Heart J. 2011;32:1769-818.

26. Corrales A, Parra JA, González-Juanatey C, et al. Cardiovascular risk stratification in rheumatic diseases: carotid ultrasound is more sensitive than Coronary Artery Calcification Score to detect subclinical atherosclerosis in patients with rheumatoid arthritis. Ann Rheum Dis. 2013;72:1764-70.

27 HAS. Insuffisance cardiaque. Guide du Parcours de soins 2014. http://www.hassante.fr/portail/icms/c 1242988/fr/guide-parcours-de-soins-insuffisance-cardiaque accessed January 27, 2016.

28 Kerlikowske K, Grady D, Rubin SM, et al. Efficacy of screening mammography. A metaanalysis. Jama 1995;273:149-54.

29. Martin-Hirsch P, Lilford R, Jarvis G, et al. Efficacy of cervical-smear collection devices: a systematic review and meta-analysis. Lancet 1999;354:1763-70.

30. Jellema $P$, van der Windt DA, Bruinvels DJ, et al. Value of symptoms and additional diagnostic tests for colorectal cancer in primary care: systematic review and meta-analysis. Bmj 2010;340:c1269.

31. HAS 2015: dépistage et prevention du cancer du sein. http://www.hassante.fr/portail/icms/c 2024559/fr/depistage-et-prevention-du-cancer-du-sein accessed January 27, 2016.

32. Ognenovski VM, Marder W, Somers EC, et al. Increased incidence of cervical intraepithelial neoplasia in women with systemic lupus erythematosus treated with intravenous cyclophosphamide. J Rheumatol 2004;31:1763-1767.

33. HAS 2013 : dépistage et prevention du cancer du col de l'utérus. http://www.hassante.fr/portail/icms/c 1623735/fr/depistage-et-prevention-du-cancer-du-col-de-l-uterus accessed January 27, 2016.

34. Salomon L, Bastide C, Beuzeboc P, et al. [CCAFU Recommendations 2013: Prostate cancer]. Prog Urol. 2013;23 Suppl 2:S69-101.

35. HAS 2012. Cancer de la prostate : identification des facteurs de risque et pertinence d'un dépistage par dosage de l'antigène spécifique prostatique (PSA) de populations d'hommes à haut risque. http://www.has-sante.fr/portail/icms/c 1238318/fr/cancer-de-la-prostateidentification-des-facteurs-de-risque-et-pertinence-d-un-depistage-par-dosage-de-I-antigenespecifique-de-la-prostate-psa-de-populations-d-hommes-a-haut-risque accessed January 27, 2016. 
36. Heidenreich A, Bastian PJ, Bellmunt J, et al; European Association of Urology. EAU guidelines on prostate cancer. part 1: screening, diagnosis, and local treatment with curative intent-update 2013. Eur Urol. 2014;65:124-37.

37. Smith RA, Manassaram-Baptiste D, Brooks D, et al. Cancer screening in the United States, 2015: a review of current American cancer society guidelines and current issues in cancer screening. CA Cancer J Clin. 2015;65:30-54.

38.HAS 2015 : dépistage et prevention du cancer colorectal. http://www.hassante.fr/portail/icms/c 1623732/fr/depistage-et-prevention-du-cancer-colorectal accessed January 27, 2016.

39. Abubakar I, Griffiths C, Ormerod P, et al. Diagnosis of active and latent tuberculosis: summary of NICE guidance. BMJ 2012;345:e6828.

40. Conroy RM, Pyorala K, Fitzgerald AP, et al. Estimation of ten-year risk of fatal cardiovascular disease in Europe: the SCORE project. European heart journal 2003;24:9871003.

41. Chen $\mathrm{HH}$, Huang N, Chen YM, et al. Association between a history of periodontitis and the risk of rheumatoid arthritis: a nationwide, population-based, case-control study. Ann Rheum Dis. 2013;72:1206-11.

42. Pischon N, Pischon T, Gülmez E, et al. Periodontal disease in patients with ankylosing spondylitis. Ann Rheum Dis. 2010;69:34-8.

43. HAS 2014. Auto-questionnaire Dépistage BPCO. http://www.hassante.fr/portail/upload/docs/application/pdf/2014-

06/questionnaire depistage bpco gold web.pdf accessed January 27, 2016.

44. Ungprasert P, Srivali N, Cheungpasitporn W, Davis lii JM. Risk of incident chronic obstructive pulmonary disease in patients with rheumatoid arthritis: A systematic review and meta-analysis. Joint Bone Spine. 2015 Dec 18. pii: S1297-319X(15)00265-1. doi: 10.1016/j.jbspin.2015.05.016. [Epub ahead of print]

45 Gochuico BR, Avila NA, Chow CK, Novero LJ, Wu HP, Ren P, MacDonald SD, Travis WD, Stylianou MP, Rosas IO. Progressive preclinical interstitial lung disease in rheumatoid arthritis. Arch Intern Med. 2008;168(2):159-66

46. van Assen S, Agmon-Levin N, Elkayam O, et al. EULAR recommendations for vaccination in adult patients with autoimmune inflammatory rheumatic diseases. Ann Rheum Dis $2011 ; 70: 414-22$.

47. Winthrop KL, Baddley JW, Chen L, et al. Association between the initiation of anti-tumor necrosis factor therapy and the risk of herpes zoster. JAMA 2013;309:887-95.

48. Brocq O, Acquacalda E, Berthier F, Albert C, Bolla G, Millasseau E, et al. Influenza and pneumococcal vaccine coverage in 584 patients taking biological therapy for chronic inflammatory joint: A retrospective study. Joint Bone Spine. 2016;83(2):155-9. 
49. Morel J, Czitrom SG, Mallick A, Sellam J, Sibilia J. Vaccinations in adults with chronic inflammatory joint disease: Immunization schedule and recommendations for patients taking synthetic or biological disease-modifying antirheumatic drugs. Joint Bone Spine. 2016 Mar;83(2):135-41.

50. Charles-Schoeman C, Burmester G, Nash P, et al. Efficacy and safety of tofacitinib following inadequate response to conventional synthetic or biological disease-modifying antirheumatic drugs. Ann Rheum Dis. 2015 Aug 14. pii: annrheumdis-2014-207178. doi: 10.1136/annrheumdis-2014-207178. [Epub ahead of print]

51. Zisman D, Bitterman $H$, Shalom $G$, et al. Psoriatic arthritis treatment and the risk of herpes zoster. Ann Rheum Dis. 2016;75:131-5.

52. Goëb V, Ardizzone M, Arnaud L et al.. Recommendations for using TNFa antagonists and French Clinical Practice Guidelines endorsed by the French National Authority for Health. Joint Bone Spine. 2013;80:574-81.

53. Hippisley-Cox J, Coupland C. Predicting risk of osteoporotic fracture in men and women in England and Wales: prospective derivation and validation of QFracture Scores. BMJ 2009;339:b4229.

54. Duru N, van der Goes MC, Jacobs JW, et al. EULAR evidence-based and consensusbased recommendations on the management of medium to high-dose glucocorticoid therapy in rheumatic diseases. Ann Rheum Dis 2013;72:1905-13.

55. Kanis JA, Johnell O, Oden A, et al. FRAX and the assessment of fracture probability in men and women from the UK. Osteoporosis international 2008;19:385-97.

56. Briot K, Cortet B, Thomas $\mathrm{T}$, et al. [Actualisation 2012 des recommendations française du traitement médicamenteux de l'ostéoporose post ménopausique]. Revue du Rhumatisme 2012;38:12.

57. Overman CL, Bossema ER, van Middendorp $\mathrm{H}$, et al. The prospective association between psychological distress and disease activity in rheumatoid arthritis: a multilevel regression analysis. Ann Rheum Dis. 2012;71:192-7.

58. National Collaborating Centre for Mental Health (UK). Depression in Adults with a Chronic Physical Health Problem: Treatment and Management. Leicester (UK): British Psychological Society; 2010. (NICE Clinical Guidelines, No. 91.) GUIDELINE DEVELOPMENT GROUP MEMBERS. Available from: http://www.ncbi.nlm.nih.gov/books/NBK82924/ PMID: 22259826

59. Canadian Task Force on Preventive Health $C$, Joffres $M$, Jaramillo A, et al. Recommendations on screening for depression in adults. Canadian Medical Association journal 2013;185:775-82.

60. Zangi HA, Ndosi M, Adams J, et al. EULAR recommendations for patient education for people with inflammatory arthritis. Ann Rheum Dis 2015;74:954-62. 
Table 1. Systematic literature review on (a) reporting presence of the comorbidity, treatment for the comorbidity, presence of risk factors for the comorbidity, and previous performance and/or results of screening or prevention procedures; and (b) existing recommendations for management.

\begin{tabular}{|l|c|c|c|}
\hline Domain of comorbidities & $\begin{array}{c}\text { Number of publications or } \\
\text { websites }\end{array}$ & $\begin{array}{c}\text { Number of publications } \\
\text { relevant to reporting (how and } \\
\text { what to report) }\end{array}$ & $\begin{array}{c}\text { Number of publications relevant to } \\
\text { management (how and when to } \\
\text { screen and to treat) }\end{array}$ \\
\hline Cardiovascular diseases & 15 & 1 & 12 \\
\hline Malignancies & 54 & 12 & 54 \\
\hline Infections & 12 & 1 & 5 \\
\hline Gastrointestinal diseases & 1 & 11 & 0 \\
\hline Osteoporosis & 11 & 3 & 5 \\
\hline Depression & 4 & 4 \\
\hline
\end{tabular}


Table 2. Overview of the pragmatic form with (a) collection or not of the different aspects: presence of the comorbidity, treatment for the comorbidity, presence of risk factors for the comorbidity, and previous performance and/or results of screening or prevention procedures; (b) proposed recommendations for management from the rheumatologist's point of view.

\begin{tabular}{|c|c|c|c|c|c|c|c|}
\hline \multirow{2}{*}{$\begin{array}{l}\text { Comorbidity } \\
\text { group }\end{array}$} & \multirow[t]{2}{*}{ Comorbidity } & \multicolumn{4}{|c|}{ Collection in the form of.... } & \multirow{2}{*}{$\begin{array}{c}\text { Proposed management by the } \\
\text { rheumatologist }\end{array}$} & \multirow[b]{2}{*}{$\begin{array}{l}\text { Agreem } \\
\text { ent } \\
\text { vote, } \\
\text { mean } \\
\text { (standa } \\
\text { rd } \\
\text { deviati } \\
\text { on) }\end{array}$} \\
\hline & & $\begin{array}{l}\text { Presence of } \\
\text { comorbidity }\end{array}$ & Treatment & Risk factors & $\begin{array}{c}\text { Screening or } \\
\text { prevention } \\
\text { performed }\end{array}$ & & \\
\hline \multirow[t]{4}{*}{$\begin{array}{l}\text { Cardio-vascular } \\
\text { diseases }\end{array}$} & Hypertension & Yes & Yes & No & $\begin{array}{l}\text { Blood pressure } \\
\text { measure }\end{array}$ & $\begin{array}{c}\text { Perform blood pressure measure: } \\
\text { once a year for all, at every visit for } \\
\text { lupus patients: referral if abnormal } \\
\text { values }\end{array}$ & $\begin{array}{c}4.82 \\
(0.45)\end{array}$ \\
\hline & Diabetes & Yes & Yes & $\begin{array}{l}\text { Obesity, high } \\
\text { waist } \\
\text { circumference, } \\
\text { family history of } \\
\text { diabetes, } \\
\text { glucocorticoids }\end{array}$ & $\begin{array}{l}\text { Fasting blood sugar } \\
\text { Body mass index } \\
\text { calculation } \\
\text { HbA1c if diabetes }\end{array}$ & $\begin{array}{c}\text { Assess fasting blood sugar every 1-3 } \\
\text { years: referral if abnormal } \\
\text { valuesWeight loss counselling if } \\
\text { overweight } \\
\text { HbA1c every } 3-6 \text { months if known } \\
\text { diabetes: referral if abnormal values }\end{array}$ & $\begin{array}{c}4.36 \\
(0.93)\end{array}$ \\
\hline & \begin{tabular}{|c|} 
Total \\
cardiovascul \\
ar risk \\
estimation
\end{tabular} & $\begin{array}{l}\text { Yes (high and } \\
\text { very high risk } \\
\text { situations) }\end{array}$ & $\begin{array}{l}\text { Yes (anti- } \\
\text { agregants/ } \\
\text { anti- } \\
\text { coagulants } \\
\text { ) }\end{array}$ & $\begin{array}{l}\text { Heart-SCORE } \\
\text { components }\end{array}$ & $\begin{array}{l}\text { Heart-SCORE } \\
\text { calculation }\end{array}$ & $\begin{array}{c}\text { Calculation of heart-SCORE at least } \\
\text { every } 5 \text { years and following major } \\
\text { changes in anti-rheumatic therapy. } \\
\text { Referral to cardiologist if Heart- } \\
\text { SCORE >1\% }\end{array}$ & $\begin{array}{c}4.31 \\
(0.81)\end{array}$ \\
\hline & $\begin{array}{l}\text { Hyperlipidem } \\
\text { ia }\end{array}$ & $\begin{array}{l}\text { Through } \\
\text { treatment }\end{array}$ & Yes & No & $\begin{array}{l}\text { LDL-cholesterol } \\
\text { assessment }\end{array}$ & $\begin{array}{c}\text { Assess LDL-cholesterol at least } \\
\text { every } 5 \text { years or following major } \\
\text { changes in anti-rheumatic therapy. } \\
\text { tocompare to target defined } \\
\text { according to total cardiovascular risk } \\
\text { estimation. Referral if target not } \\
\text { reached. }\end{array}$ & $\begin{array}{c}4.44 \\
(0.68)\end{array}$ \\
\hline
\end{tabular}




\begin{tabular}{|c|c|c|c|c|c|c|c|}
\hline & Heart failure & Yes & No & No & $\begin{array}{l}\text { Symptoms at clinical } \\
\text { examination }\end{array}$ & Referral if symptoms & $\begin{array}{c}4.46 \\
(0.72)\end{array}$ \\
\hline \multirow[t]{7}{*}{ Malignancies } & $\begin{array}{l}\text { Breast } \\
\text { cancer }\end{array}$ & Yes & No & Family history & Mammography & \begin{tabular}{|c|} 
Recommend/prescribe \\
mammography every 2 years for age \\
$50-75$. \\
If risk factors, referral.
\end{tabular} & $\begin{array}{c}4.56 \\
(0.69)\end{array}$ \\
\hline & $\begin{array}{l}\text { Cervix } \\
\text { cancer }\end{array}$ & Yes & No & No & $\begin{array}{l}\text { Cervical smear } \\
\text { Human Papilloma } \\
\text { Virus (HPV) } \\
\text { vaccination }\end{array}$ & $\begin{array}{c}\text { Recommend/prescribe cervical } \\
\text { smear every } 3 \text { years for age } 25-65 \text { if } \\
\text { sexual activity, if } 2 \text { smears one year } \\
\text { apart are normal } \\
\text { If abnormal smear, referral. } \\
\text { Recommend HPV vaccination for } \\
\text { girls age } 11-14 \text { years. }\end{array}$ & $\begin{array}{c}4.62 \\
(0.69)\end{array}$ \\
\hline & $\begin{array}{l}\text { Prostate } \\
\text { cancer }\end{array}$ & Yes & No & $\begin{array}{l}\text { Yes (symptoms } \\
\text { or family history } \\
\text { or ethnic risk - } \\
\text { Afro-Carribean } \\
\text { origin) }\end{array}$ & No & If risk factors, referral & $\begin{array}{c}4.50 \\
(0.77)\end{array}$ \\
\hline & Lung cancer & Yes & No & Yes (smoking) & No & $\begin{array}{l}\text { If smoking, recommend referral to } \\
\text { encourage interruption }\end{array}$ & $\begin{array}{c}3.90 \\
(1.21)\end{array}$ \\
\hline & Lymphoma & Yes & No & No & $\begin{array}{c}\text { Adenopathy clinical } \\
\text { examination }\end{array}$ & $\begin{array}{l}\text { Perform adenopathy clinical } \\
\text { examination once a year }\end{array}$ & $\begin{array}{c}4.30 \\
(1.15)\end{array}$ \\
\hline & $\begin{array}{l}\text { Colorectal } \\
\text { cancer }\end{array}$ & Yes & No & \begin{tabular}{|c|} 
Yes \\
(inflammatory \\
bowel disease, \\
polyps, family \\
history)
\end{tabular} & \begin{tabular}{|c|} 
Faecal \\
immunochemical test \\
or faecal occult blood \\
test \\
Colonoscopy
\end{tabular} & $\begin{array}{l}\text { Recommend/prescribe feacal blood } \\
\text { test every } 2 \text { years if age } 50-74 \\
\text { If risk factors, referral }\end{array}$ & $\begin{array}{c}4.41 \\
(0.93)\end{array}$ \\
\hline & Skin cancer & Yes & No & No & $\begin{array}{c}\text { Clinical examination } \\
\text { by dermatologist }\end{array}$ & $\begin{array}{c}\text { Refer for clinical examination by } \\
\text { dermatologist at least once in lifetime }\end{array}$ & $\begin{array}{c}4.00 \\
(1.25)\end{array}$ \\
\hline Infections & Tuberculosis & $\begin{array}{l}\text { Yes (active } \\
\text { disease or just } \\
\text { positivity of } \\
\text { screening } \\
\text { tests) } \\
\end{array}$ & $\begin{array}{c}\text { Yes } \\
\text { (treatment } \\
\text { if } \\
\text { tuberculosi } \\
\text { s) }\end{array}$ & $\begin{array}{l}\text { Yes (social } \\
\text { status, drug } \\
\text { use, contact } \\
\text { with } \\
\text { tuberculosis) }\end{array}$ & Vaccination status & Screen for tuberculosis if risk factors & $\begin{array}{c}3.78 \\
(1.31)\end{array}$ \\
\hline
\end{tabular}




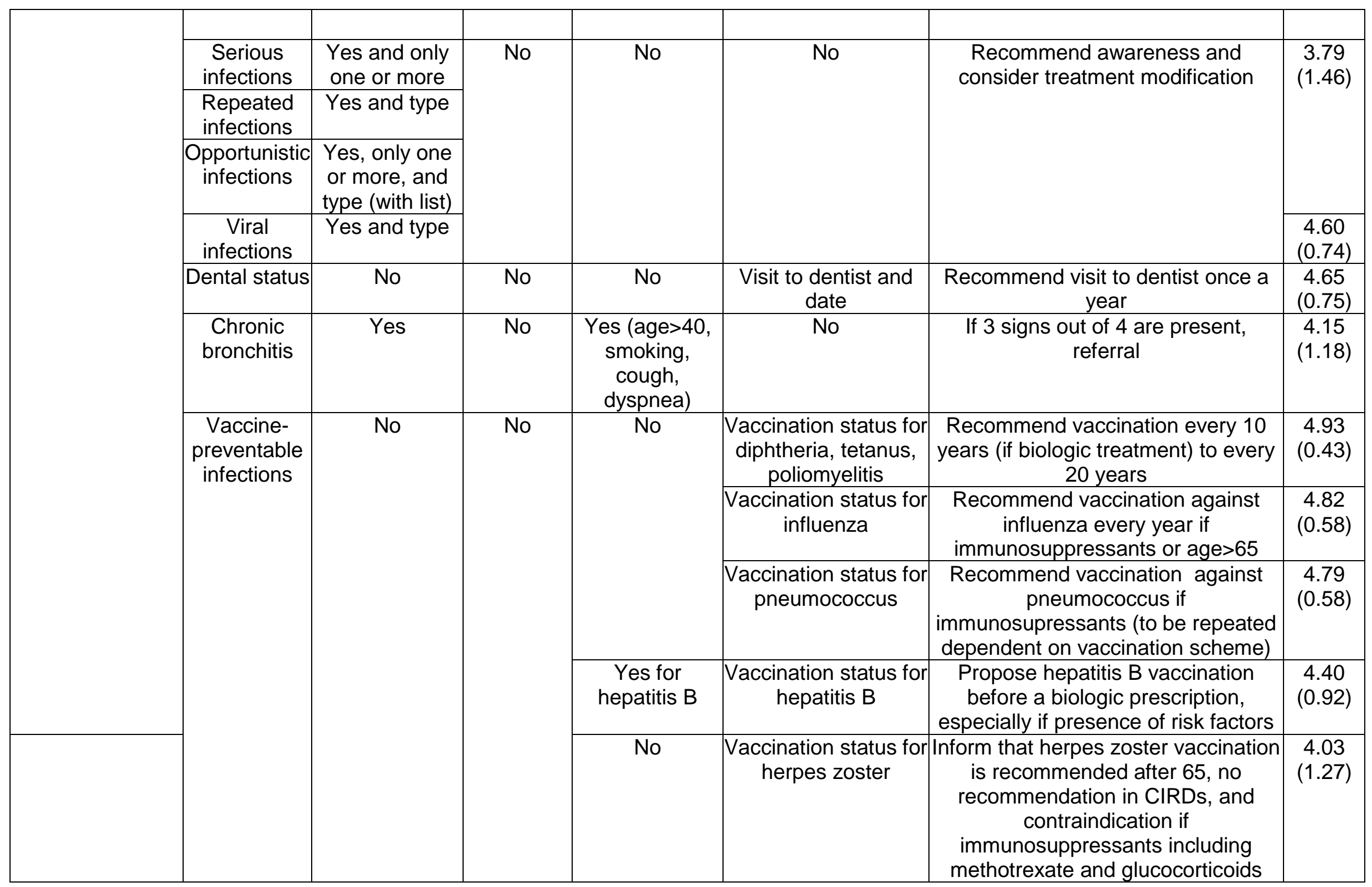




\begin{tabular}{|c|c|c|c|c|c|c|c|}
\hline & & & & & & (live vaccine) & \\
\hline $\begin{array}{l}\text { Gastrointestinal } \\
\text { diseases }\end{array}$ & Diverticulitis & Yes & No & No & No & $\begin{array}{l}\text { If present take into account when } \\
\text { prescribing glucocorticoids/NSAIDs. }\end{array}$ & $\begin{array}{c}4.53 \\
(0.98)\end{array}$ \\
\hline \multirow[t]{3}{*}{ Osteoporosis } & Fractures & Yes & No & See below & Height loss $>4 \mathrm{~cm}$ & $\begin{array}{l}\text { Prescription of treatment if major } \\
\text { osteoporotic fracture } \\
\text { Prescription of spine radiographs if } \\
\text { height loss }>4 \mathrm{~cm}\end{array}$ & $\begin{array}{c}4.63 \\
(0.61)\end{array}$ \\
\hline & \multirow[t]{2}{*}{$\begin{array}{c}\text { Osteoporosis } \\
\text { risk factors }\end{array}$} & No & No & See below & $\begin{array}{c}\text { Bone mineral density } \\
\text { result }\end{array}$ & $\begin{array}{c}\text { Prescription of bone mineral density } \\
\text { (a) in the general population if } \\
\text { presence of risk factors for } \\
\text { osteoporosis, (b) in menopausal } \\
\text { women if presence of risk factors, (c) } \\
\text { in patients with CIRDs at least once } \\
\text { in lifetime }\end{array}$ & $\begin{array}{l}4.30 \\
(0.86)\end{array}$ \\
\hline & & No & No & $\begin{array}{c}\text { Yes } \\
\text { (components of } \\
\text { FRAX score) }\end{array}$ & FRAX calculation & $\begin{array}{c}\text { Calculation of FRAX score if age } \\
>40, \quad \text { T Score }>-3 \text { Standard } \\
\text { Deviations and either non major } \\
\text { osteoporotic fracture OR risk factors. } \\
\text {. } \\
\text { Consider treatment if values above } \\
\text { threshold. }\end{array}$ & $\begin{array}{c}4.00 \\
(1.35)\end{array}$ \\
\hline Depression & Depression & Yes & No & $\begin{array}{c}\text { Yes (history of } \\
\text { depression or } \\
\text { of anti- } \\
\text { depressant } \\
\text { treatment) }\end{array}$ & No & None & $\begin{array}{c}3.90 \\
(1.52)\end{array}$ \\
\hline
\end{tabular}


Online supplementary Table 1. Literature review methods to collect information on comorbidity management in CIRDs

\begin{tabular}{|c|c|c|c|c|c|c|}
\hline Domains & $\begin{array}{l}\text { Cardiovascular } \\
\text { diseases }\end{array}$ & Infections & Cancers & $\begin{array}{l}\text { Gastro-intestinal } \\
\text { diseases }\end{array}$ & Osteoporosis & Depression \\
\hline $\begin{array}{l}\text { Key words for } \\
\text { search in } \\
\text { PubMed } \\
\text { Medline in July } \\
2015\end{array}$ & $\begin{array}{l}\text { ((("Arthritis, } \\
\text { Psoriatic"[Mesh] OR } \\
\text { "Arthritis, } \\
\text { Rheumatoid"[Mesh] } \\
\text { OR } \\
\text { "Spondylarthritis"[M } \\
\text { esh] OR "Lupus } \\
\text { Erythematosus, } \\
\text { Systemic"[Mesh] } \\
\text { OR "Spondylitis, } \\
\text { Ankylosing"[Mesh] } \\
\text { OR "Anti-Neutrophil } \\
\text { Cytoplasmic } \\
\text { Antibody- } \\
\text { Associated } \\
\text { Vasculitis"[Mesh]) } \\
\text { AND } \\
\text { ("Cardiovascular } \\
\text { Diseases"[Majr] OR } \\
\text { "Cardiovascular } \\
\text { System"[Majr] OR } \\
\text { "Myocardial } \\
\text { Infarction"[Mesh] } \\
\text { OR "Heart } \\
\text { Failure"[Mesh] OR } \\
\text { "Peripheral Arterial } \\
\text { Disease"[Mesh])) } \\
\text { OR cardiovascular } \\
\text { risk OR } \\
\text { "Dyslipidemias"[Maj } \\
\text { r] OR } \\
\text { "Hypertension"[Majr }\end{array}$ & $\begin{array}{l}\text { infection/di } \\
\text { [Diagnosis / } \\
\text { OR “infection } \\
\text { prevention/ } \\
\text { (Guideline[pt } \\
\text { yp] OR } \\
\text { Practice } \\
\text { Guideline[pty } \\
\text { p]) }\end{array}$ & 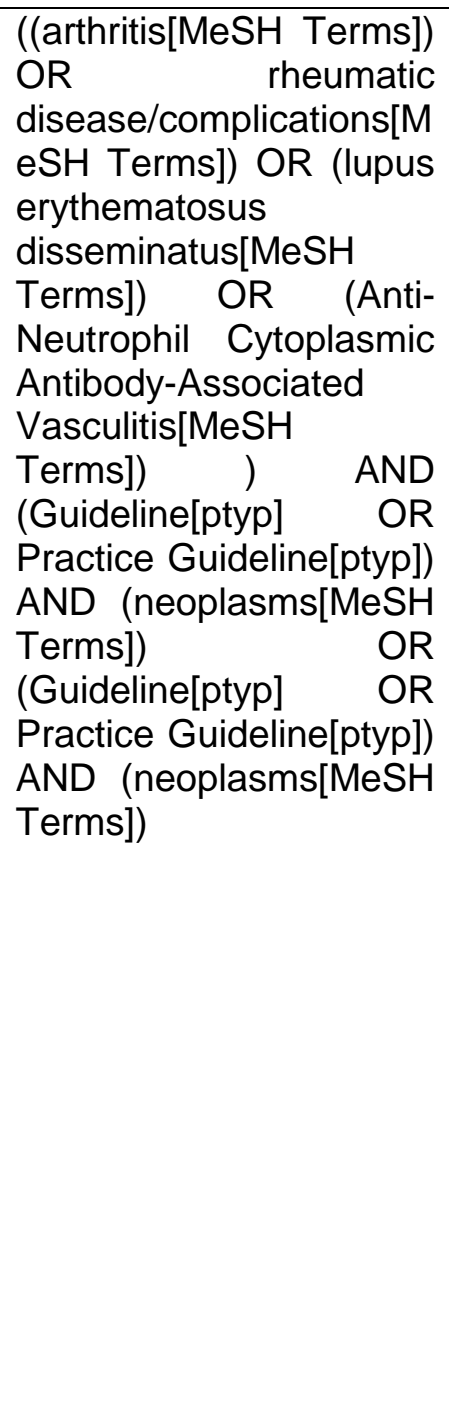 & $\begin{array}{l}\text { ("Diverticulitis"[M } \\
\text { esh] AND } \\
\text { (Guideline[ptyp] } \\
\text { OR Practice } \\
\text { Guideline[ptyp]) }\end{array}$ & $\begin{array}{l}\text { “exp } \\
\text { osteoporosis/ } \\
\text { (Guideline[pt } \\
\text { yp] OR } \\
\text { Practice } \\
\text { Guideline[pty } \\
\text { p]) }\end{array}$ & 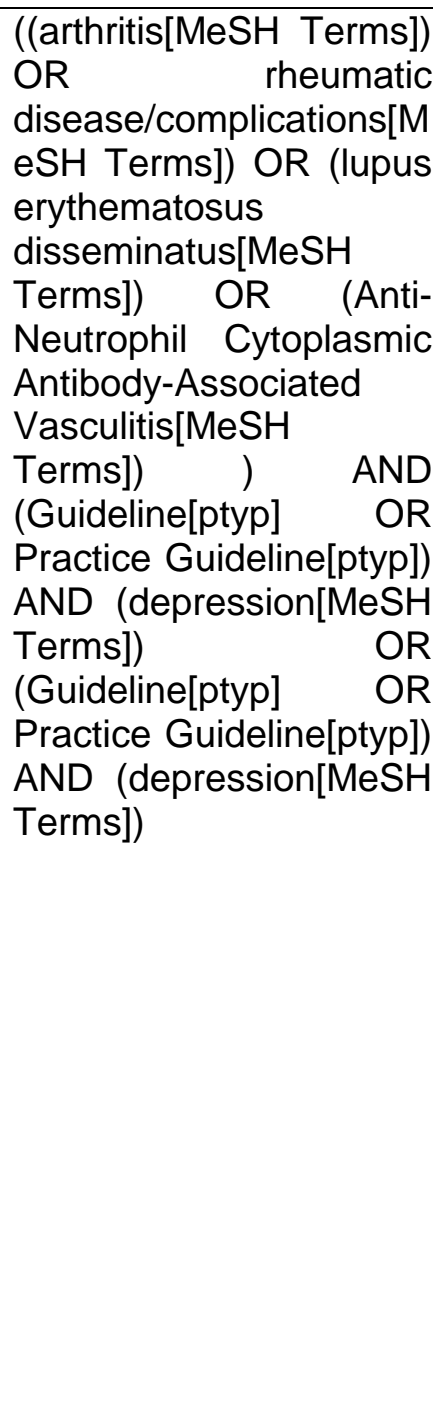 \\
\hline
\end{tabular}




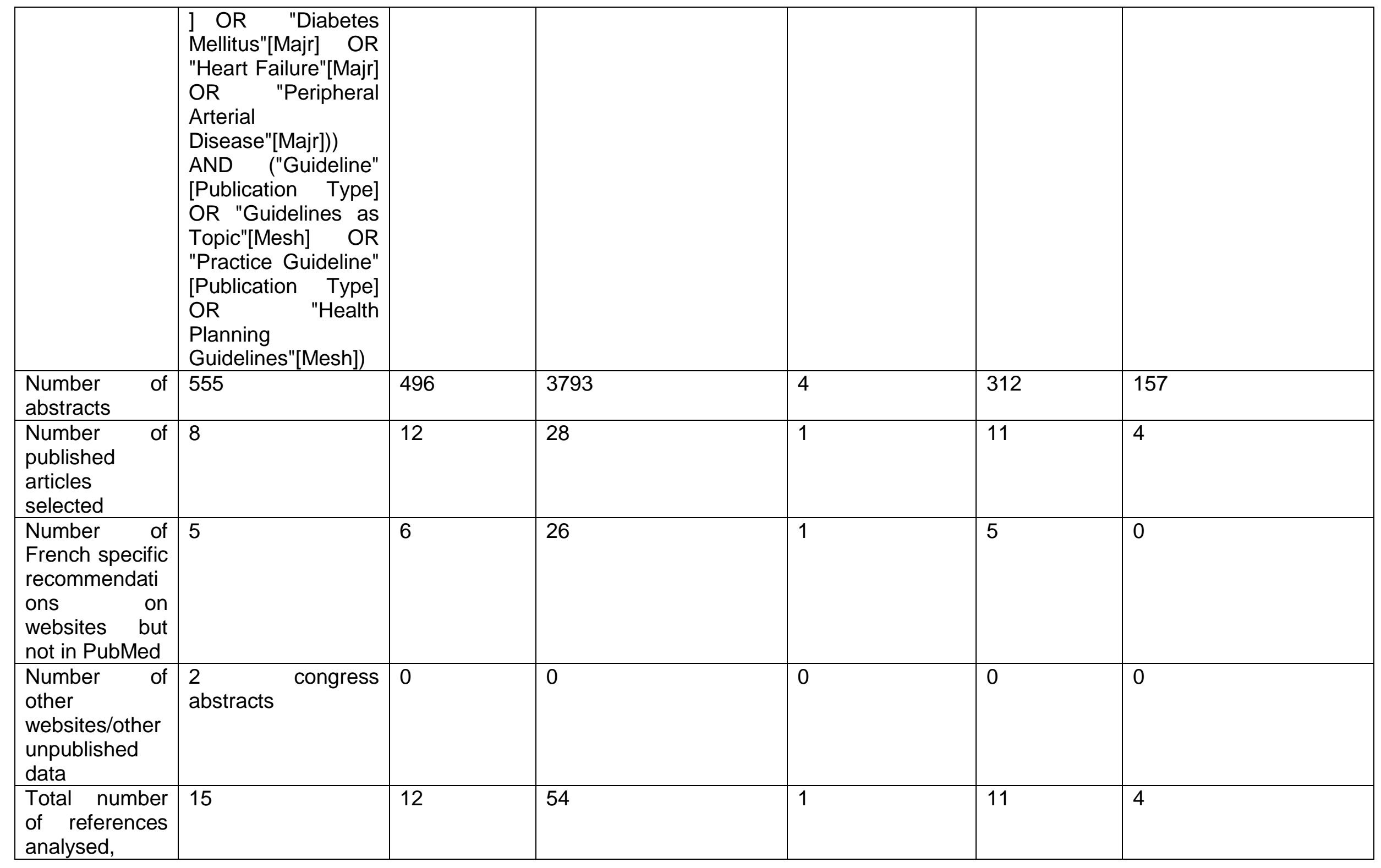


including

articles

and

websites 
